\title{
Credit Management Guidelines to Strengthen Thai Industrial Sector
}

\author{
Chittikhun KULCHITTIVEJ ${ }^{1}$, Pairat PORNPUNDEJWITTAYA ${ }^{2}$, Thanin SILPCHARU ${ }^{3}$
}

Received: July 01, 2020 Revised: July 19, 2020 Accepted: August 10, 2020

\begin{abstract}
This research investigates the credit management guidelines to strengthen Thai industrial sector. The research has been simulated from the findings of both qualitative and quantitative of 500 questionnaires distributed to industrial business executives in Thailand. The data were analyzed by descriptive analysis categorized into SME and large enterprises, and SEM to conduct the model in consistent with the empirical data. The results show that: (1) the credit management guidelines consist of 4 factors: a) characteristics management b) financial management c) operations management and d) assets management. The business executives gave overall importance on the guidelines at a high level with an average of 3.86. (2) The development of SEM shows that the model fits with the empirical data at Chi-Square probability level $=0.084, \mathrm{CMIN} / \mathrm{DF}=1.164, \mathrm{GFI}=0.965$ and $\mathrm{RMSEA}=0.018$. (3) The characteristics management directly influences the financial management and the operation management. The financial management directly influences on the assets management. The assets management has direct influence on the operations management. The findings show that the characteristics management is the essential starting component in SEM and the financial management factor has the most influence in the assets management variable with standard regression weight of 0.990 .
\end{abstract}

Keywords: Credit Management, Loan Borrowing, Thai Industrial Sector, Thailand

JEL Classification Code: E51, H81, L26

\section{Introduction}

The industrial sector is an important sector that drives the country's economy and has always played an important role in the country's economic development. As can be seen from the proportion of the Gross Domestic Product (GDP) of the industrial sector during 2014-2018, it is accounted for an average of 74 percent of the country's GDP. In 2018, the industrial sector had a GDP of 373.3 billion USD, which equivalent to 75 percent of the country's GDP (Office of the

${ }^{1}$ First Author and Corresponding Author. Doctoral Student, Faculty of Business Administration, King Mongkut's University of Technology North Bangkok, Thailand [Postal Address: 1518 Pracharat 1 Road, Wongsawang, Bangsue, Bangkok 10800 Thailand]

Email: chittikhun@gmail.com; s5714011950011@email.kmutnb.ac.th

${ }^{2}$ Assistant Professor, Faculty of Business Administration, King Mongkut's University of Technology North Bangkok, Thailand.

${ }^{3}$ Professor, Faculty of Business Administration, King Mongkut's University of Technology North Bangkok, Thailand.

(c) Copyright: The Author(s)

This is an Open Access article distributed under the terms of the Creative Commons Attribution Non-Commercial License (https://creativecommons.org/licenses/by-nc/4.0/) which permits unrestricted non-commercial use, distribution, and reproduction in any medium, provided the original work is properly cited.
National Economic and Social Development Council, 2019). Therefore, it is undeniable that the industrial sector is an important mechanism to drive the country's economy.

At the same time, the source of loans from commercial banks is one of the main factors driving the industrial sector, evidenced by the increasing trend of loans outstanding of industrial businesses (Bank of Thailand, 2019). Nevertheless, the report of the Credit Conditions Survey of the Bank of Thailand has found that the credit approval ratio tends to decrease from the Diffusion Index (DI) (Monetary Policy Strategy Division at Bank of Thailand, 2019). The DI index number is between -100 and 100 for which the central banks in many countries have used it to examine the credit conditions and trends. There are also further researches on DI index (Bassett, Chosak, Driscoll \& Zakrajšek, 2014; van der Veer \& Hoeberichts 2016) by weighted average score from a 5-level scale and weighted by the corresponding share of outstanding loan for each financial institution.

Commercial banks grant loans to industrial businesses every year, seeing from the increase of loan outstanding in 2014 of 233.0 billion USD to 266.7 billion USD in 2018 , while the non-performing loans tend to increase; from 3.3 
billion USD in 2014 to 6.0 billion USD in 2018. Moreover, when considered non-performing ratio, it is found that the ratio is likely to increase from 1.4 percent in 2014 to 2.3 percent in 2018 (Bank of Thailand, 2019). It shows that as commercial banks granting more credit to the business sector, the amount of non-performing loans also increases. It is because the business sector is unable to repay the debt due to shortage of cash flow from operations, resulting to weak Thai industrial sector.

Therefore, the problem can be summarized that the business organization of Thailand deficiencies credit management. Then, this research has conducted to develop the Structural Equation Modeling (SEM) of the credit management approach to strengthen Thai industrial sector. If the business organization has good management guidelines, the bank will provide a credit facility and also the business organization would be good debt serviceability. It will additionally lead to stable and sustainable business growth and robustness of the Thai industry.

\section{Literature Review and Hypothesis}

\subsection{Characteristics Management}

Characteristics management refers to guidelines for managing organizational characteristics in order to likely receive credit approval as well as being able to repay bank debt. Therefore, the concepts and theories related to characteristics management are under good ethics and management with social and environmental responsibility (Corporate Social Responsibility) (Brigham \& Ehrhardt, 2013) which leads to sustainable development. Also, a business organization should have good corporate governance (Baker \& Anderson, 2010) which means the effective management of a company, honesty, accountability, and consideration for all stakeholders, including the creation of shared economic values or Corporate Shared Value (Porter \& Kramer, 2011), which is a guideline for creating mutual benefits between the benefits of a business organization and benefits for the society. Moreover, the business organization should use the McKinsey 7-S Model (Channon \& Caldart, 2015) in management by analyzing all 7 variables which are important to the success of the organization by using the analysis results according to the principles to formulate strategies to maximize benefits and efficiency for the organization management. Finally, the business organization shall apply customer relationship management concept (Burtonshaw-Gunn, 2009) which is any process or activity that generate satisfaction in products and services. Then it will create customer loyalty in the brand and build good relations with the organization by benefiting both parties, the customers and the organization (win-win strategy) continuously for a long time.

\subsection{Financial Management}

Financial management states that the guidelines for managing corporate finance in order to the business organization is strong enough to receive credit approval as well as being able to repay bank debt. Therefore, the concepts and theories related to financial management are feasibility study (Justis \& Kreigsmann, 1979; Palepu \& Healy, 2008) which is to ensure that the selected project is feasible, has possible return or benefit that is worth the investment and able to use resources efficiently. The project must not cause any impact on the environment and society afterward and can achieve the objectives set under limited budget and time. Moreover, financial statement analysis and financial ratio (White, Sondhi, \& Fried, 2003; Ross, Westerfield, \& Jordan, 2010) are important numbers for finding facts about financial status and performance of the project or business.

The financial ratios are comparison of two or more financial statements in order to interpret the relationship in which the results are shown in percentage, or proportion, or duration, or even number of rounds and the number of times. Also, the business organization should has budgeting (Lalli, 2012; Bragg, 2013). The budget serves as an estimate of future operation based on production capacity. In cost accounting, the budget can be divided into 2 types; fixed budget, an estimate of predetermined income and expenses which once prepared will not change according to the changes in activity level, and flexible budget, financial plans created for different activity levels which can be adjusted freely based on the output. Additionally, the business organization should use artificial intelligence ("AI") (Chishti \& Barberis, 2016) in the field of financial technology (Boobier, 2018) in the organization. AI can be used in a variety of financial applications, such as optical character recognition, speech recognition, and machine learning that can learn and can predict data through studies and creating algorithms. Eventually, the business organization must select financial risk issues (Hitchner, 2010; Merna \& Al-Thani, 2011) that are important to manage financial risk of firm. The business organization have prepared in advance to be ready for any issue due to the connection of the financial markets causing the risk that may occur at some point far away in the world, resulting in the unexpected severe impact to the Thai market.

\subsection{Operations Management}

Operations management mentions approaches to managing operations that is likely to obtain credit approval as well as being able to repay bank debt. Therefore, the concepts and theories related to operations management are the product life cycle (Levin \& Kalal, 2003), which will provide an understanding of the product life cycle from the beginning until the end which varies according to the time of 
product enters into the market. The conceptual framework has classified the product life cycle into 4 phases consisting of introduction, growth, maturity, and decline. Also, a business organization still requires raw material management.

One of the important principles of Just in Time (Salvendy, 2001) is the concept of well-timed raw material management, with the concept of producing or delivering the products that customers need in the time needed with the required amount by seizing the needs of customers to determine the number of raw materials used in production. Moreover, the business organization should has inventory management. Firstly, the concept of ABC analysis (Bragg, 2011.) is an inventory management concept to create a suitable amount of production and to reduce the cost of raw material management which classifies the importance level of raw materials into 3 types; very important, moderately important, and least important. Secondly, supply chain management or moving process from the beginning of raw material to finish goods for customers through efficient management processes (Hugos, 2018). Lastly, logistics management (Belvedere \& Grando, 2017) is the concept of the operational planning process to control the efficiency of the product/service circulation. It covers the procurement of raw materials, warehouse management, transportation and cost management.

\subsection{Assets Management}

Assets management raises guidelines for managing business assets to strengthen the organization's credibility to increase credit approval as well as being able to repay bank debt. Therefore, the concepts and theories related to assets management are asset life cycle (Manase, 2015). A business organization should prepare assets management plans to ensure that the business organization operations efficiency and continuously. In addition, the business organization should has an asset valuation by an appraisal company certified by the bank. There are 3 methods of appraising assets, which are market method, cost method and income method (Hood \& Lee, 2011). The valuation shall be appraisal every year in order to use the such assets as collateral with the bank since the bank requires securities or guarantees to reduce the risk of the business organization from not paying back their debts (Menkhoff, Neuberger \& Rungruxsirivorn, 2012; Majumdar, 2014) for which the guarantor may be an individual or a juristic person depending on the requirement of the bank.

However, according to the past, there are only 2 ways to eligible collateral: pledge and mortgage. According to the law, it allows the pledger to specifically pledge its movable property and must deliver the pledged property to the pawnbroker. As for mortgages, the law stipulates that mortgages can only be real estate or certain types of unmovable property. However, this limitation has been unlocked and opened new options for the access to capital with the floating charge (Kothari, 2006). The key is to bring assets with economic value as collateral without delivering them. Ultimately, the business organization shall regularly conduct insurance policy in order to reduce business and financial risk (Culp, 2011).

\subsection{Related Research}

Nguyen and Wolfe (2016) conducted the research about determinants of successful access to bank loans by Vietnamese SMEs: new evidence from the red river delta. The purpose of this study is to analysis the factors affecting the availability and affordability of SME loans in Vietnam with the results that factors affect SME borrowing can be classified into four groups: relationship lending (number of relations with lending banks or years in the relationship), transaction based lending (requirement for audited financial statements, average number of used services), asset-based lending (total assets, fixed assets, equity, real estate, commercial paper and inventory) and other factors (characteristics of SMEs or the sector that SMEs operate in, distance between banks and clients, guarantees from the VDB and credit policy). Of these, they find that collateral plays a leading role in credit making decisions and the second most important factor is the number of relationships SMEs have with banks.

Trinh and Phuong (2016) examined the effects of financial crisis on capital structure of listed firms in Vietnam. The purpose of this research is to investigate the relation between the leverage and firm size, growth, profitability, tangibility, together with crisis dummies is built based on a sample of 265 firms listed on Hanoi Stock Exchange and Ho Chi Minh City Stock Exchange. It was found that firm size, profitability, and tangibility (measured by the ratio between fixed assets and total assets) have statistically significant impacts on capital structure. The growth of total assets is not statistically significant in explaining the variance of the leverage. The study result also reveals that capital structure of Vietnamese listed firms has not changed significantly under the financial crisis.

Araujo and Hambur (2018) investigated the characteristics of firms to whether their applications for credit were approved with the purposes to improve understanding on how lenders assess firms' creditworthiness. The results revealed that a firm's financial health, as measured by financial ratios (gearing ratio, debt-service ratio, returns on assets and liquidity ratio), appears to be important in determining whether they will have their application for credit accepted. Firms with relatively low profitability or high debt-service ratio appear less likely to have their applications approved. There is also some evidence that firms with little credit 
history, as captured by a lower gearing ratio, are less likely to receive credit.

Ramli, Latan and Solovida (2019) conducted the research about determinants of capital structure and firm financial performance-A PLS-SEM approach: Evidence from Malaysia and Indonesia. The purpose of this research is to examine the impact of capital structure determinants on firm financial performance together with the mediation effect of firm leverage in Malaysia and Indonesia over the period of 1990-2010. The results discovered that only the Malaysian sample has a positive significant correlation between firm leverage and firm financial performance. Firm leverage plays a mediating role in Malaysia but not for the Indonesian sample. Certain attribute coefficients in the determinants of capital structure and firm financial performance are significantly different between Malaysia and Indonesia.

Le and Le (2020) investigated the determinants of lending decision from Binh Duonag province's banks in Vietnam. The purpose of this research is to investigate what determinant effects for loan approval. The results found that firm's collateral was the most positive factor to bank lending decision, follow by firm's business plan. The role of company's leader is very important for banks considers to approve credit because firm's leaders experience and relationship with stakeholders as well as banks have positive relations with bank's lending decision. The firm's financial statement and firm's credit history with banks are also significant factors for lending decision. Nevertheless, the business environment (the main business sector of the firm which is stable or has growth potential) might not affected lending decision as their relations is not substantial.

Nguyen and Nguyen (2020) examined the impact of the statement of cash flows of listed companies on lending decisions of commercial banks in the context of Vietnam. The results show that (1) the information on the cash flow statement affects both the short-term and long-term lending decisions of credit officers, (2) the lack of information on the cash flow statement in both cases of positive and negative profits affects the comfort and confidence of credit officers in making decisions, and (3) cash flow statements are important for lending decisions of credit institutions in Vietnam. Thus, this research provides a new perception to managers on how to improve the quality of cash flow statement to meet the needs of lenders.

With the reasons above, the researcher has an interest in conducting credit management guidelines to strengthen Thai industrial sector. The study focuses on causal factors influencing successfully operating industrial business. It is expected that the findings of this study will yield guidelines in 4 important factors: a) characteristics management b) financial management c) operations management and d) assets management in order to create more access to finance and enhance the potential and strength of Thai industrial sector.

\subsection{Hypothesis}

According to Amacha and Dastane (2017) found that the sustainability practices (measured by Australian Council of Superannuation Investors) is positively related to financial performance (EBITDA margin, Earnings per share and $\mathrm{P} / \mathrm{E}$ Ratio) at the significance level of 0.01. Thus, the sustainability practices is positively linked to financial performance. Ha (2020) discovered the factor of mission, involvement, adaptability and consistency have positively affected the operation performance (ROA, ROE and Profit after Tax) with the significance level of $0.05 ; 0.01 ; 0.01 ; 001$, respectively. Thus, the organizational culture is positively connected with financial performance. Therefore, the first hypothesis is suggested as follows:

H1: The characteristics management variable directly influences the financial management variable

As reported by Bond-Barnard, Fletcher and Steyn (2018), the degree of collaboration strongly influences the project management success with a standard regression coefficient $=0.792$. Then, project management success becomes more likely as the degree of collaboration increases. Besides, Hoang and Ngoc (2019) discovered that the attitude of leader has positive relationship with firm's performance (effects on processes) at the significance level of 0.05 as well as the attitude of leader has positive relationship with innovation capability (process innovation) at the significance level of 0.01 . Then, a positive relationship is detected between leadership attitude and firm operation. Subsequently, the second hypothesis is recommended as follows:

H2: the characteristics management variable directly influences the operations management variable

Referring to Chipeta and Deressa (2016) stated that total debt ratio has a relationship with tangibility (collateral value of assets) in South Africa, Tanzania (at the significance level of 0.001), in Botswana (at the significance level of 0.01) and Mauritius \& Namibia (at the significance level of 0.05). Hence, firm profitability is the most common significant predictor of capital structure for firms in Sub-Saharan Africa. Furthermore, Anderson, Bahaj, Chavaz, Foulis and Pinter (2018) indicated that investment activity variable directly influences value of corporate collateral variable at the significance level of 0.001 . Accordingly, lending relationships insulate corporate investment from fluctuations in collateral values. As a result, the third hypothesis is proposed as follows:

H3: the financial management variable directly influences the assets management variable 
Based on Imran, Hameed and Haque (2018) indicated that smart factory has a significant relationship with production and services at the significance level of 0.001. Therefore, the results demonstrate that better implementation of smart factory technologies will lead to higher production and services. Moreover, Haseeb, Hussain, Slusarczyk, and Jermsittiparsert (2019) showed that smart factory significantly relates with IT implementation at the significance level of 0.05 . Accordingly, smart factory has a positive role in promoting information technology implementation. Consequently, the fourth hypothesis is recommended as follows:

H4: the assets management variable directly influences the operations management variable

From the mentioned above, this researcher proposed the research framework as shown in Figure 1.

\section{Research Methods}

This study was designed as a mixed-methodology process that was qualitative and quantitative research:

\subsection{Qualitative Research}

The data from this qualitative research were developed from an in-depth interview that was assembled by the researcher in the form of open-ended questions that were based on the review literature. The informants were 9 experts with the qualifications that were required by the criteria. The results from the interview were engaged to develop questionnaires in the form of rating scales.

\subsection{Quantitative Research}

The data for the quantitative research were derived from previous studies and the content analysis of in-depth interviews to create a research tool. The instrument of this study was separated into two parts: 1) the general business status, which were determined by using checklist questions; 2) the character of credit management, where all items were measured by using a 5-point Likert scale ranging from 1 ("Strongly Unimportant") to 5 ("Strongly Important"); and 3) opinions and suggestions. The questionnaires were validated by 5 specialists with a content validation between 0.6 and 1.0, the reliability of Cronbach's alpha $=0.976$, a discriminant analysis of the question item with the correlated item-total correlation was between 0.302 and 0.840 , the overall SD (standard deviation) of the checklist was between 0.380 and 1.950 . After passing the validation with a very good result, the questionnaires were used to collect data from 500 business executives (MacCallum, Widaman, Zhang, \& Hong, 1999; Comrey \& Lee, 2013). Thus, the results of the questionnaires were used to construct the simulation model.

\subsection{Data Analysis}

The data were evaluated by both descriptive statistics and inferential statistics using the SPSS program. Multivariate statistical analysis and SEM were conducted through AMOS. There were 4 statistic variables that were used to evaluate the data model fit on AMOS (Arbuckle, 2011): 1) the chi-squared probability level: $\mathrm{p} \geq 0.05 ; 2$ ) relative chisquared $(\mathrm{CMIN} / \mathrm{DF}) \leq 2.0 ; 3)$ the goodness of fit index (GFI) $\geq 0.90$; and 4$)$ the root mean square error of approximation $($ RMSEA $) \leq 0.08$.

\subsection{Samples}

The questionnaires were distributed to the samples from July 2019 to October 2019. In total, 500 contributors presented a summary of the general business status in Table 1 . The majority of company's registration were company limited $(70.60 \%)$ with $10-20$ years of business operations $(41.0 \%)$, business size $50 \%$ of small \& medium and $50 \%$ of large, industry classification of service $39.6 \%$ and business type of consumer goods (58.4\%).

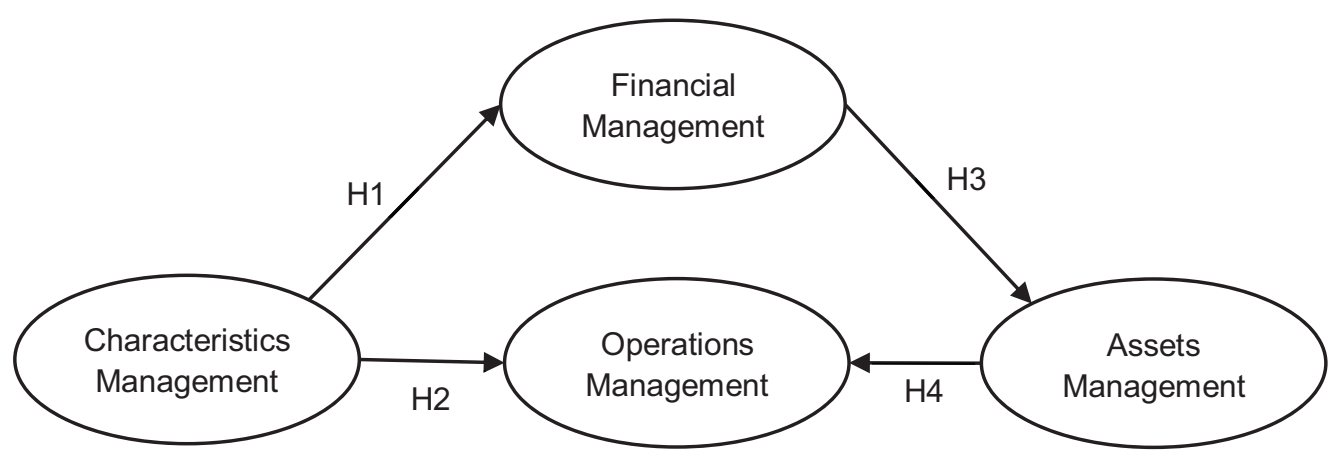

Figure 1: Research framework 
Table 1: Results of general business status

\begin{tabular}{|l|l|c|c|}
\hline Category & \multicolumn{1}{|c|}{ Item } & Frequency (n = 500) & Percentage \\
\hline \multirow{4}{*}{ Company's registration } & Limited Partnership & 103 & 20.60 \\
\cline { 2 - 4 } & Company Limited & 353 & 70.60 \\
\cline { 2 - 4 } & Public Company Limited & 44 & 8.80 \\
\hline \multirow{4}{*}{ Business duration } & $<10$ years & 103 & 20.60 \\
\cline { 2 - 4 } & $10-20$ years & 205 & 41.00 \\
\cline { 2 - 4 } & $>20$ years & 192 & 38.40 \\
\hline \multirow{3}{*}{ Industry classification } & Small and medium & 250 & 50.00 \\
\cline { 2 - 4 } & Large & 250 & 50.00 \\
\hline \multirow{5}{*}{ Business type } & Raw materials & 194 & 38.80 \\
\cline { 2 - 4 } & Manufacturing & 108 & 21.60 \\
\cline { 2 - 4 } & Service & 198 & 39.60 \\
\hline & Agriculture \& Agro-Industry & 52 & 10.40 \\
\cline { 2 - 4 } & Consumer Goods & 292 & 58.40 \\
\cline { 2 - 4 } & Industrial & 64 & 12.80 \\
\cline { 2 - 4 } & Real Estate \& Construction & 63 & 12.60 \\
\cline { 2 - 4 } & Technology & 29 & 5.80 \\
\hline
\end{tabular}

\section{Results and Discussion}

\subsection{Qualitative Research}

The qualitative results from the in-depth interview showed that the model for credit management guidelines to strengthen Thai industrial sector consists of four main components: 1) characteristics management, 2) financial management, 3) operations management, and 4) assets management. The data were then used to write 120 questions (30 questions under each component).

\subsection{Quantitative Research}

The quantitative results revealed that the important level of the variables in credit management guidelines was at a high level with an average of 3.86. When considering each item, it was found that all four variables were rated at a high level, with the highest variable rating being for assets management with 3.89 , followed by financial management with 3.87 , characteristics management with 3.85 , and operations management with 3.84 . When comparing the different sizes of business and the importance level of the four variables, it was discovered that there was no statistical difference.

\subsection{Structural Equation Modeling}

The results of the data model fit evaluation of the SEM model of credit management guidelines were: RMSEA $=0.059$, passed the evaluation criteria. However, the chi-squared probability level $=0.000$, the CMIN/ $\mathrm{DF}=2.732$, and the GFI $=0.510$, which did not pass the evaluation. Therefore, the researcher adjusted the simulation model by considering the modification indices that were suggested by (Arbuckle 2011). After the adjustment, the chi-squared probability level was 0.084 , the $\mathrm{CMIN} / \mathrm{DF}=1.164$, GFI $=0.965$, and the RMSEA $=$ 0.018; thus, the four statistics level passed the evaluation criteria. The final refined structural equation model with standardized coefficients and factor loadings is shown in Figure 2 and Table $2-3$. 


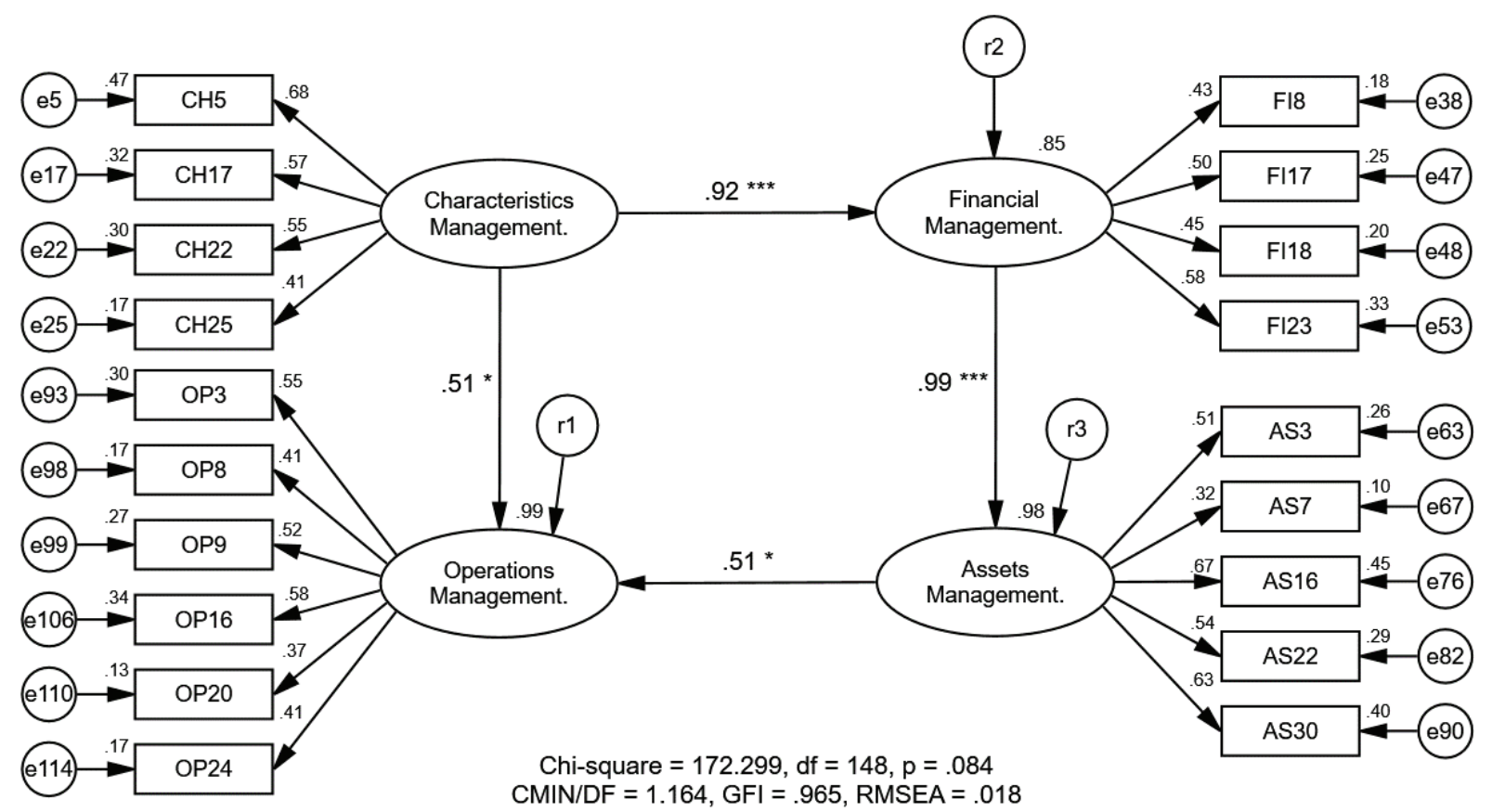

Figure 2: Measurement of overall model fit in SEM

Table 2: Structural model results and hypothesis testing

\begin{tabular}{|c|c|c|c|c|c|c|}
\hline Hypothesis & Path Coefficient & Std. $\beta$ & SE & CR & $p$-Value & Result \\
\hline $\mathrm{H} 1$ & Characteristics Mgmt. $\rightarrow$ Financial Mgmt. & 0.922 & 0.064 & 7.931 & *** & Support \\
\hline $\mathrm{H} 2$ & Characteristics Mgmt. $\rightarrow$ Operations Mgmt. & 0.509 & 0.179 & 2.055 & * & Support \\
\hline H3 & Financial Mgmt. $\rightarrow$ Assets Mgmt. & 0.990 & 0.171 & 7.426 & *** & Support \\
\hline $\mathrm{H} 4$ & Assets Mgmt. $\rightarrow$ Operations Mgmt. & 0.510 & 0.249 & 2.096 & * & Support \\
\hline
\end{tabular}

Note: ${ }^{* * *}: p<0.001,{ }^{*}: p<0.05$, Mgmt.: Management, SE: Standard Error, CR: Critical Ratio

The characteristics management aspect directly influences the financial management aspect with the statistical significance at 0.001 and standard regression weight at 0.922 . Then, the hypothesis $\mathrm{H} 1$ is accepted. As a business organization has good management of firm characteristics, the result shows that the organization has good financial status and financial performance (Abrahams \& Zhang, 2009; Rose \& Hudgins, 2013) in accordance with the previous research of Amacha and Dastane (2017) and Ha (2020). For example, focusing on maintaining credit with financial institutions means that a business organization can repay loans and interest on time which will result in good payment record. Thus, the business organization has good financial status and operating results so that it has cash flow to repay loans. In addition, the business organization produces product based on the trend and not destroying the environment, which refers to the business organization applying the principles of corporate social responsibility. Moreover, the business organization adopts the good governance, the principles to manage the company with efficiency, transparency, accountability, and consideration for all stakeholders, as a guideline for managing organization characteristics. Therefore, business product is able to sell because buyer selects the products relied on the trend and such products do not destroy the environment which will make a business organization have revenue growth and profits. Lastly, there will be cash flow to pay off the debt.

The characteristics management aspect directly influences the operation management aspect with the statistical significance at 0.05 and standard regression weight at 0.509 . Thus, the hypothesis $\mathrm{H} 2$ is accepted. Since a business organization has good management 
of firm characteristics, it will result in performing well operations (Baker \& Anderson, 2010; Brigham \& Ehrhardt, 2013) in line of prior study of Bond-Barnard, Fletcher and Steyn (2018) and Hoang and Ngoc (2019). For instance, developing good relationships with stakeholders' means the organization is able to respond to the needs and expectations of its stakeholders and makes engagement with stakeholders in an integral part of corporate governance, strategies and work processes which will result in smooth operation of the organization. Besides, when the business organization focuses on creating quality working teams, meaning the business organization is able to perform their tasks well by creating activities and working together. This will encourage everyone to understand the importance and principles of teamwork together with raising awareness about responsibility, cooperation, and encouragement to use brainstorming. As a result, individual in the team will have good relations with each other as well as have coexistence and collaboration skills. Once the team is mature and effective, it will result in effective organization operations.

The financial management aspect directly influences on the assets management aspect with the statistical significance at 0.001 with standard regression weight of 0.990. Therefore, the hypothesis H3 is accepted. As business organization increases its assets by creating debts or increasing investment, it affects its assets by increasing the value of assets of business organization (Fabozzi \& Peterson, 2003; Vernimmen, Quiry, Dallocchio, Le Fur \& Salvi, 2009) according to the earlier study of Chipeta and Deressa (2016) and Anderson, Bahaj, Chavaz, Foulis and Pinter (2018). To illustrate, if the business organization has financial management by keeping low debt to equity ratio or low leverage, it will result in the growth of the assets since the business organization uses both debt and equity to support its assets at a level acceptable to financial institutions. However, if the business organization uses too much debt to support the organization's assets, financial institutions will opine the business organization with high leverage ratio which is a level that financial institutions cannot accept and there is a very low chance of credit approved. Moreover, if business organization manages leverage structure to the level that the loan requested is lower than collateral value, it will finally get credit approval as financial institutions accepts LTV less than or equal to $100 \%$.

Table 3: Measurement model results of observed variable indicators.

\begin{tabular}{|c|c|c|c|c|c|}
\hline Latent Construct & Observed Variable & Factor Loading & $R^{2}$ & CR & $p$-Value \\
\hline \multirow{4}{*}{$\begin{array}{l}\text { Characteristics } \\
\text { Management }\end{array}$} & $\mathrm{CH} 5$ & 0.684 & 0.468 & & \\
\hline & $\mathrm{CH} 17$ & 0.565 & 0.320 & 10.999 & $* * *$ \\
\hline & $\mathrm{CH} 22$ & 0.550 & 0.303 & 10.728 & $* * *$ \\
\hline & $\mathrm{CH} 25$ & 0.406 & 0.165 & 8.089 & $* * *$ \\
\hline \multirow{4}{*}{$\begin{array}{l}\text { Financial } \\
\text { Management }\end{array}$} & $\mathrm{Fl8}$ & 0.430 & 0.185 & & \\
\hline & FI17 & 0.504 & 0.255 & 7.583 & $* * *$ \\
\hline & FI18 & 0.446 & 0.199 & 7.078 & $* * *$ \\
\hline & $\mathrm{Fl} 23$ & 0.577 & 0.333 & 8.104 & $* * *$ \\
\hline \multirow{6}{*}{$\begin{array}{l}\text { Operations } \\
\text { Management }\end{array}$} & OP3 & 0.552 & 0.305 & & \\
\hline & OP8 & 0.412 & 0.169 & 7.747 & $* * *$ \\
\hline & OP9 & 0.523 & 0.274 & 9.326 & $* * *$ \\
\hline & OP16 & 0.582 & 0.338 & 10.048 & $* * *$ \\
\hline & OP20 & 0.365 & 0.133 & 7.015 & $* * *$ \\
\hline & OP24 & 0.414 & 0.172 & 7.789 & $* * *$ \\
\hline \multirow{5}{*}{$\begin{array}{l}\text { Assets } \\
\text { Management }\end{array}$} & AS3 & 0.507 & 0.257 & & \\
\hline & AS7 & 0.316 & 0.100 & 5.964 & $* * *$ \\
\hline & AS16 & 0.671 & 0.450 & 10.057 & $* \star *$ \\
\hline & AS22 & 0.536 & 0.287 & 8.838 & $* * *$ \\
\hline & AS30 & 0.632 & 0.400 & 9.743 & $* \star *$ \\
\hline
\end{tabular}

Note: ${ }^{* * *}: p<0.001 ; \mathrm{CR}$ : Critical Ratio; CH5, FI8, OP3 and AS3 are defaulted parameter at 1. 
The assets management aspect has direct influence on the operations management aspect with the statistical significance at 0.05 with factor loading of 0.510 . Hence, the hypothesis H4 is accepted. Since a business organization has good management of assets, it will result in performing well operations (Bragg \& Burton, 2006; King, 2011) following the former research Imran, Hameed and Haque (2018) and Haseeb, Hussain, Slusarczyk, and Jermsittiparsert (2019). In particular, proper filing of assets and documents will result in better operations management. It is because the business organization has gathered data and documents of assets well. Hence, it enables the organization to proceed with production in accordance with the actual inventory data (work in process \& finished good) as well as procure enough raw materials for production, which will ensure smooth the operations. Furthermore, if the business organization has a system to monitor and maintain business assets; it will ensure efficient production operations since the production operations use corporate assets. On the contrary, if a business organization does not have a system to monitor and maintain assets, the organization will result in production instability, such as goods during production or raw materials may be lost or missing. Accordingly, the business organization will not be able to produce finished goods relied on the production plan.

\section{Conclusion}

According to the study of a structural equation model of credit management guidelines to strengthening Thai industrial sector, it can be concluded that the aspects that are important to the credit management approach consist of 4 main factors: characteristics management, operations management, financial management, and assets management. The result shows the characteristics management directly influences the financial management and the operation management with the statistical significance at 0.001 and 0.05 , respectively. The financial management directly influences on the assets management with the statistical significance at 0.001 . The assets management has direct influence on the operations management with the statistical significance at 0.05. Also, the findings show that the characteristics management is the essential starting component in SEM and the financial management factor has the most influence in the assets management variable with standard regression weight at 0.990 .

Therefore, if the business organization has utilized the best guidelines for credit management as mentioned in Table 3, it will increase the potential of industrial business to access more borrowing as well as the ability to repay bank debt. As a result, business organization will have stable and sustainable growth which will lead to further robust the Thai industrial sector.

\section{References}

Abrahams, C. R., \& Zhang, M. (2009). Credit risk assessment: the new lending system for borrowers, lenders, and investors (Vol. 22). Hoboken, NJ: John Wiley \& Sons.

Amacha, E., \& Dastane, O. (2017). Sustainability practices as determinants of financial performance: A Case of Malaysian Corporations. Journal of Asian Finance, Economics and Business, 4(2), 55-68. http://dx.doi.org/10.13106/jafeb.2017. vol4.no2.55

Anderson, G., Bahaj, S., Chavaz, M., Foulis, A., \& Pinter, G. (2018). Lending relationships and the collateral channel. Bank of England Working Paper No. 768. Retrieved April 1, 2020 from: https://papers.ssrn.com/sol3/papers.cfm?abstract id $=3287212$

Araujo, G., \& Hambur, J. (2018). Which Firms Get Credit? Evidence from Firm-level Data. Reserve Bank of Australia: Bulletin-December Quarter 2018. Retrieved April 1, 2020 from: https://www.rba.gov.au/publications/bulletin/2018/dec/ which-firms-get-credit-evidence-from-firm-level-data.html

Arbuckle, J. L. (2011). IBM SPSS Amos 20 user's guide. Chicago, IL: Amos Development Corporation, SPSS Inc.

Baker, H. K., \& Anderson, R. (Eds.). (2010). Corporate governance: A synthesis of theory, research, and practice (Vol. 8). Hoboken, NJ: John Wiley \& Sons.

Bank of Thailand. (2019). NPLs and Loans Outstanding. Retrieved December 15, 2019 from: https://www.bot.or.th/English/ Statistics/FinancialInstitutions/Pages/StatNPLsOutstanding. aspx [in Thai]

Bassett, W. F., Chosak, M. B., Driscoll, J. C., \& Zakrajšek, E. (2014). Changes in bank lending standards and the macroeconomy. Journal of Monetary Economics, 62, 23-40.

Belvedere, V., \& Grando, A. (2017). Sustainable operations and supply chain management. Hoboken, NJ: John Wiley \& Sons.

Bond-Barnard, T. J., Fletcher, L., \& Steyn, H. (2018). Linking trust and collaboration in project teams to project management success. International Journal of Project Management, 26(8), 821-829. doi: 10.1016/j.ijproman.2007.11.004.

Boobier, T. (2018). Advanced Analytics and AI: impact, implementation, and the future of work. Hoboken, NJ: John Wiley \& Sons.

Bragg, S. M. (2011). Inventory best practices. Hoboken, NJ: Wiley Online Library.

Bragg, S. M. (2013). Accounting best practices. Hoboken, NJ: John Wiley \& Sons.

Bragg, S. M., \& Burton, E. (2006). Accounting and finance for your small business. Hoboken, NJ: John Wiley \& Sons.

Brigham, E. F., \& Ehrhardt, M. C. (2013). Financial management: Theory \& practice. Boston, MA: Cengage Learning.

Burtonshaw-Gunn, S. (2009). The essential management toolbox: Tools, models and notes for managers and consultants. Hoboken, NJ: John Wiley \& Sons. 
Channon, D. F., \& Caldart, A. A. (2015). McKinsey 7S model. Wiley Encyclopedia of Management, Volume 12. Strategic Management. https://doi.org/10.1002/9781118785317. weom 120005

Chipeta, C., \& Deressa, C. (2016). Firm and country specific determinants of capital structure in Sub Saharan Africa. International Journal of Emerging Markets, 11(4), 649-673. https://doi.org/10.1108/IJoEM-04-2015-0082

Chishti, S., \& Barberis, J. (2016). The FinTech book: the financial technology handbook for investors, entrepreneurs and visionaries. Hoboken, NJ: John Wiley \& Sons.

Comrey, A. L., \& Lee, H. B. (2013). A first course in factor analysis. London, UK: Psychology Press.

Culp, C. L. (2011). Structured finance and insurance: the ART of managing capital and risk (Vol. 339). Hoboken, NJ: John Wiley \& Sons.

Fabozzi, F. J., \& Peterson, P. P. (2003). Financial management and analysis (Vol. 132). Hoboken, NJ: John Wiley \& Sons.

Ha, V. D. (2020). Impact of Organizational Culture on the Accounting Information System and Operational Performance of Small and Medium Sized Enterprises in Ho Chi Minh City. Journal of Asian Finance, Economics, and Business, 7(2), 301-308. https://doi.org/10.13106/jafeb.2020.vo17.no2.301

Haseeb, M., Hussain, H. I., Ślusarczyk, B., \& Jermsittiparsert, K. (2019). Industry 4.0: A solution towards technology challenges of sustainable business performance. Social Sciences, 8(5), 154.

Hitchner, J. (2010). Financial Valuation, Website: Applications and Models (Vol. 545). Hoboken, NJ: John Wiley \& Sons.

Hoang, C. C., \& Ngoc, B. H. (2019). The Relationship between Innovation Capability and Firm's Performance in Electronic Companies, Vietnam. Journal of Asian Finance, Economics and Business, 6(3), 295-304. https://doi.org/10.13106/jafeb.2019. vol6.no3.295

Hood Jr, L. P., \& Lee, T. R. (2011). A Reviewer's Handbook to Business Valuation: Practical Guidance to the Use and Abuse of a Business Appraisal. Hoboken, NJ: John Wiley \& Sons.

Hugos, M. H. (2018). Essentials of supply chain management. Hoboken, NJ: John Wiley \& Sons.

Imran, M., Hameed, W., \& Haque, A. (2018). Influence of industry 4.0 on the production and service sectors in Pakistan: Evidence from textile and logistics industries. Social Sciences, 7(12), 246. https://doi.org/10.3390/socsci7120246

Justis, R. Y., \& Kreigsmann, B. (1979). The feasibility study as a tool for venture analysis. Journal of Small Business Management, 17(1), 35-42.

King, A. M. (2011). Internal control of fixed assets: a controller and auditor's guide (Vol. 564). Hoboken, NJ: John Wiley \& Sons.

Kothari, V. (2006). Securitization: the financial instrument of the future (Vol. 385). Hoboken, NJ: John Wiley \& Sons.

Lalli, W. R. (2012). Handbook of Budgeting (Vol. 562). Hoboken, NJ: John Wiley \& Sons.
Le, M. T., \& Le, D. N. T. (2020). Developing Traditional Handcraft Villages: The Determinants of Lending Decision from Binh Duong Province's Banks in Vietnam. Journal of Asian Finance, Economics, and Business, 7(2), 151-156. https://doi. org/10.13106/jafeb.2020.vol7.no2.151

Levin, M. A., \& Kalal, T. T. (2003). Improving product reliability: strategies and implementation (Vol. 1). Hoboken, NJ: John Wiley \& Sons.

MacCallum, R. C., Widaman, K. F., Zhang, S., \& Hong, S. (1999). Sample size in factor analysis. Psychological Methods, 4(1), 84-99. https://doi.org/10.1037/1082-989X.4.1.84

Majumdar, R. (2014). The determinants of indebtedness of unlisted manufacturing firms in India. Management Research Review, 37(9), 833-854. https://doi.org/10.1108/MRR-09-2012-0193

Manase, D. (2015). Public Sector Property Asset Management. Hoboken, NJ: Wiley Online Library.

Menkhoff, L., Neuberger, D., \& Rungruxsirivorn, O. (2012). Collateral and its substitutes in emerging markets' lending. Journal of Banking \& Finance, 36(3), 817-834.

Merna, T., \& Al-Thani, F. F. (2011). Corporate risk management. Hoboken, NJ: John Wiley \& Sons.

Monetary Policy Strategy Division at Bank of Thailand. (2019). Credit Conditions Report. Retrieved December 15, 2019 from: https://www.bot.or.th/English/MonetaryPolicy/ EconomicConditions/Pages/CreditCondition.aspx [in Thai]

Nguyen, D. D., \& Nguyen, A. H. (2020). The Impact of Cash Flow Statement on Lending Decision of Commercial Banks: Evidence from Vietnam. Journal of Asian Finance, Economics, and Business, 7(6), 85-93. https://doi.org/10.13106/jafeb.2020. vol7.no6.085

Nguyen, S., \& Wolfe, S. (2016). Determinants of successful access to bank loans by Vietnamese SMEs: new evidence from the red river delta. The Journal of Internet Banking and Commerce. 21(1), 1-23.

Office of the National Economic and Social Development Council. (2019). Gross Domestic Product Chain Volume Measures. All tables QGDP (Download Excel File). Retrieved December 15, 2019 from: https://www.nesdc.go.th/main. php?filename $=$ qgdp_page [in Thai]

Palepu, K. G., \& Healy, P. M. (2008). Business Analysis \& Valuation: Using Financial Statements ( $4^{\text {th }}$ ed.). Mason, OH: Thomson Higher Education.

Porter, M. E., \& Kramer, M. R. (2011). The Big Idea: Creating Shared Value. How to reinvent capitalism - and unleash a wave of innovation and growth. Harvard Business Review, 89(1-2). https://hbr.org/2011/01/the-big-idea-creating-shared-value

Ramli, N. A., Latan, H., \& Solovida, G. T. (2019). Determinants of capital structure and firm financial performance-A PLSSEM approach: Evidence from Malaysia and Indonesia. The Quarterly Review of Economics and Finance, 71, 148-160.

Rose, P., \& Hudgins, S. (2013). Bank Management \& Financial Services (9th ed.). Singapore: McGraw-Hill. 
Ross, S. A., Westerfield, R., \& Jordan, B. D. (2010). Fundamentals of corporate finance. New- Delhi, India: Tata McGraw-Hill Education.

Salvendy, G. (2001). Handbook of industrial engineering: technology and operations management. Hoboken, NJ: John Wiley \& Sons.

Trinh, T. H., \& Phuong, N. T. (2016). Effects of financial crisis on capital structure of listed firms in Vietnam. International Journal of Financial Research, 7(1), 66-74. van der Veer, K. J., \& Hoeberichts, M. M. (2016). The level effect of bank lending standards on business lending. Journal of Banking \& Finance, 66, 79-88.

Vernimmen, P., Quiry, P., Dallocchio, M., Le Fur, Y., \& Salvi, A. (2009). Corporate finance: theory and practice. Hoboken, NJ: John Wiley \& Sons.

White, G. I., Sondhi, A. C., \& Fried, D. (2003). The analysis and use of financial statements (Vol. 1). Hoboken, NJ: John Wiley \& Sons. 


\section{Appendix}

\begin{tabular}{|c|c|}
\hline \multicolumn{2}{|c|}{ Abbreviation Definitions } \\
\hline \multicolumn{2}{|c|}{ Characteristics management } \\
\hline $\mathrm{CH} 5$ & To focus on maintaining credit with financial institutions \\
\hline $\mathrm{CH} 17$ & To develop good relationships with stakeholders \\
\hline $\mathrm{CH} 22$ & To build a quality team \\
\hline $\mathrm{CH} 25$ & To produce products in accordance with the trend and not destroying the environment \\
\hline \multicolumn{2}{|c|}{ Financial Management } \\
\hline $\mathrm{Fl8}$ & To maintain debt to equity ratio (Debt/Equity) to be at an appropriate level. \\
\hline FI17 & To have assets that are valued sufficiently to be used as collateral for loans \\
\hline FI18 & To reserve money to pay off long-term debt, for example, to redeem debentures or to pay off loans \\
\hline $\mathrm{FI} 23$ & To regularly assess financial risks and effects \\
\hline \multicolumn{2}{|c|}{ Operations Management } \\
\hline OP3 & To recruit quality work teams \\
\hline OP8 & To operate under the laws and regulations of the relevant government \\
\hline OP9 & To continue production and adhere to production plans. \\
\hline OP16 & To adopt modern machines for production to increase production and produce good quality products \\
\hline OP20 & To plan production for maximum efficiency \\
\hline OP24 & To have an accounting system and flowchart \\
\hline \multicolumn{2}{|c|}{ Assets management } \\
\hline AS3 & To preserve assets \\
\hline AS7 & To conduct insurance policy for damage and loss of corporate assets \\
\hline AS16 & To appraise assets according to the bank's requirements from a recognized appraisal company \\
\hline AS22 & $\begin{array}{l}\text { To file information and property documents (such as tools used in the production of goods, inventories, or } \\
\text { raw materials used in the production of goods) so that they can be properly collateralized under the Business } \\
\text { Security Act. }\end{array}$ \\
\hline AS30 & To have a system to inspect and maintain assets of the organization \\
\hline
\end{tabular}

